\title{
A multi-disciplinarily designed mesocosm to address the complex flow-sediment-ecology tripartite relationship on the microscale
}

\author{
Holger Schmidt ${ }^{1}$, Moritz Thom ${ }^{1}$, Kerstin Matthies², Sebastian Behrens ${ }^{3}$, Ursula Obst ${ }^{2}$, Silke Wieprecht ${ }^{1}$ \\ and Sabine Ulrike Gerbersdorf ${ }^{1 *}$
}

\begin{abstract}
Background: The stabilization of fine sediments via biofilms ('biostabilization') has various economic and ecological implications but is presently unaddressed within lotic waters. To investigate natural biofilm growth and functionality in freshwater sediments under controlled boundary conditions, a unique mesocosm was constructed that combines established know-how from engineering and natural sciences and consists of six straight flumes. To test the comparability of biofilm growth within one flume and between the flumes, extracellular polymeric substances (EPSs), microbial biomass and microbial community composition were closely monitored over time and space as well as in relation to biofilm adhesiveness (proxy for biostabilization).

Results: Most importantly, biofilm development and biostabilization capacity revealed no significant differences within flume regions or between the flumes and the biofilms significantly stabilized the substratum as compared to abiotic controls. However, interesting temporal successions in biofilm growth phases became visible in shifting abundance and diversity of bacteria and microalgae resulting in varying EPS secretion and biostabilization.

Conclusions: These findings demonstrated the importance of biostabilization for fine sediment dynamics in freshwaters. Secondly, this unique setup allows comparable biofilm growth under controlled environmental conditions, an important requisite for future research on the ecological significance and impact of biostabilization for ecosystem functioning at varying environmental scenarios.
\end{abstract}

Keywords: Biofilm; Biostabilization; Sediment stability; Adhesion; Extracellular polymeric substances (EPSs); MagPI; DGGE; Flume; Diatoms

\section{Background}

During biofilm growth, microbes secrete extracellular polymeric substances (EPSs) gluing cells to the sediment and sediment particles to each other. Hereby, especially fine sediments ( 0.02 to $0.2 \mathrm{~mm}$ ) are granted a higher resistance against erosive processes [1,2]. This constitutes a significant ecosystem service with broad economic and ecological implications. Understanding the dynamics of fine sediments is essential for maintaining waterways, dams and harbours, e.g. biostabilized fine sediments can significantly complicate reservoir flushing. Additionally,

\footnotetext{
* Correspondence: sabine.gerbersdorf@iws.uni-stuttgart.de ${ }^{1}$ Institute for Modelling Hydraulic and Environmental Systems, University Stuttgart, Pfaffenwaldring 61, 70569 Stuttgart, Germany Full list of author information is available at the end of the article
}

a high quantity of macro and micropollutants can bind to fine sediment grains (and its organic matrix) to be jointly deposited in river regions with lower flow velocities $[3,4]$. The immobilization of pollutants within sediments largely depends on the substratum stability. Thus, biofilms can delay or prevent the re-suspension of these legacies into the water body as well as their bioavailability, while microbial bioremediation might even degrade those substances.

Knowledge about biostabilization of fine sediments is steadily increasing, and new techniques to measure adhesiveness of biofilms at high resolution have been established [5-7]. Moreover, the influence of various environmental factors on the formation of biofilms has been investigated, mostly by experimental procedures (e.g. [8,9]). In the 
laboratory, parameters can be adjusted and reproduced relatively easy while insights into interspecies relations and larger-scaled ecosystem developments are limited, especially since most studies concentrate on monospecies biofilm (e.g. $[10,11])$. Other projects focused on field observations that illustrate diverse ecological phenomena $[12,13]$. Nevertheless, the environmental conditions are barely controllable and it is difficult to unravel specific links between species abundances, community composition, physiology and ecosystem functionality.

The presented project maximizes the advantages of laboratory (controlled reproducible settings) and field investigations (natural relevance) while combining engineering and biological expertise. Several studies investigated biofilm formation in microcosms [14-16]. Here, a continuous flow system is used consisting of six straight flumes run with natural river water. Detailed information about the construction, the hydraulic regimes and flow velocities of the straight flumes are given in Thom et al. [17]. The new flow channel system is unique because of the following: (1) the flume dimensions guarantee fully developed turbulence, uniform water flow and constant discharge as important requirements in hydraulic research; (2) the inoculation and development of biofilm from natural water on natural-like substratum minimizes behavioural artefacts of the microorganisms as a response to a more artificial physical environment and (3) microbial growth and development can be linked to biofilm functionality, here biostabilization as one important ecosystem service. Thereby, well-established methods from engineering science meet protocols in microbial and chemical analysis as well as molecular approaches to gain insights into the process of biostabilization with its various complex interactions. However, the main focus of the present paper is the evaluation of the newly designed straight flume setup with respect to the following question: is biofilm growth and development within and between the individual flumes comparable under controlled boundary conditions despite the well-known heterogeneity of natural waters? This is an essential prerequisite for further research into the phenomenon biostabilization at different habitats and environmental scenarios in order to reliably relate the manipulated boundary conditions to the observed effects on biofilm functionality. A 4-week experiment was conducted in which biofilm growth was evaluated intra-flume and inter-flume wise. The analytical focus of this study was on biochemical and molecular biological parameters of the developing biofilm and on biofilm adhesiveness as a proxy for substratum stability.

\section{Results}

Water chemistry

Nutrient concentrations of the water samples were constant over the experimental time and except for nitrate, at the detection limit (according to LAWA [18]): phosphate < $0.2 \mathrm{mg} \mathrm{L}^{-1}$, ammonium and nitrate approx. $0.04 \pm 0.03$ and $2.9 \pm 0.1 \mathrm{mg} \mathrm{L}^{-1}$, respectively, and sulphate with $48.1 \pm$ $0.4 \mathrm{mg} \mathrm{L}^{-1}$. Concentrations of fluoride and chloride were below 0.2 and around $58.7 \pm 0.7 \mathrm{mg} \mathrm{L}^{-1}$, respectively.

\section{Inter- and intra-flume comparison}

Comparison of the data on biochemical analysis, microbial biomass and surface adhesiveness showed no significant difference neither between the different regions within one flume nor between the different flumes (Tables 1, 2 and 3).

\section{Development of the biofilm during the experiment EPS matrix}

Generally, contents of colloidal EPS carbohydrates and proteins exhibited an overall increase throughout the experiment (Figure 1), e.g. mean carbohydrate contents increased about fourfold from $11.6 \pm 3.5 \mu \mathrm{gDW}^{-1}$ (day 2) to $42.8 \pm 13.4 \mu \mathrm{g} \mathrm{gDW}^{-1}$ (day 26) while mean protein values increased about fivefold from $1.0 \pm 0.8 \mu \mathrm{g} \mathrm{gDW}^{-1}$ to $5.2 \pm 3.0 \mu \mathrm{g} \mathrm{gDW}^{-1}$. However, the increase between two subsequent sampling points was only significant between days 11 and 14, for EPS carbohydrates (KWT; $n=$ $120 ; p=0.0162$ ) as well as for EPS proteins (KWT; $n=$ $120 ; p<0.0001)$. Nevertheless, the mean values measured from day 14 onwards were significantly higher than those determined until day 7 (for both, EPS carbohydrates and proteins: KWT; $n=120 ; p<0.0001$ ). Overall, the contents of EPS carbohydrates and proteins showed a strong positive correlation during the experiment (Spearman; rs $=0.70 ; n=120 ; p<0.0001$ ).

\section{Chlorophyll a content and bacterial cell counts}

Chlorophyll $a$ contents and bacterial cell counts (BCC) increased during the experiment (Figure 2). For instance, mean chlorophyll $a$ contents increased from $0.1 \pm 0.1 \mu \mathrm{g}$ $\mathrm{gDW}^{-1}$ (day 2) to $3.7 \pm 2.1 \mu \mathrm{g} \mathrm{gDW}^{-1}$ (day 26). Meanwhile, mean BCC increased tenfold from $4.6 \pm 1.1 \times 10^{6}$ $\mathrm{gDW}^{-1}$ to $4.3 \pm 1.4 \times 10^{7} \mathrm{gDW}^{-1}$. Thus, highly significant differences were detected for both parameters between earlier biofilm stages (until day 7) and matured biofilms (from day 22 onwards) (KWT; $p<0.0001 ; n=$ 120 for chlorophyll $a ; n=40$ for BCC).

However, while BCC showed significant increases from day 5 to day 7 and from day 7 to day 11 (KWT; $n=40$; $p=0.0471$ and $p=0.0074$, respectively), the values dropped significantly from day 11 to day 14 (KWT; $n=$ 40; $p=0.0009$ ). In contrast, chlorophyll $a$ increased significantly from day 11 to day 14 (KWT; $n=120 ; p=$ 0.0210), with an even more pronounced microalgal growth between day 14 to day 18 (KWT; $n=120 ; p=$ 0.0053). Over the total experimental time, BCC and chlorophyll $a$ as a proxy for algal biomass were positively 
Table 1 Intra-flume comparison

\begin{tabular}{|c|c|c|c|c|c|}
\hline Flume region & $\begin{array}{l}\text { Carbohydrates } \\
\left(\mu \mathrm{g} \mathrm{gDW}{ }^{-1}\right)\end{array}$ & $\begin{array}{l}\text { Proteins } \\
\left(\mu \mathrm{g} \mathrm{gDW} \mathrm{gW}^{-1}\right)\end{array}$ & $\begin{array}{l}\text { Chlorophyll } a \\
\left(\mu \mathrm{g} \mathrm{gDW}{ }^{-1}\right)\end{array}$ & $\begin{array}{l}\text { Bacterial cells } \\
\left(10^{7} \mathrm{gDW}^{-1}\right)\end{array}$ & $\begin{array}{l}\text { Surface adhesiveness } \\
\text { (mA) }\end{array}$ \\
\hline Front & $27.9 \pm 12.5$ & $2.4 \pm 1.6$ & $1.3 \pm 1.6$ & $1.5 \pm 0.8$ & $618 \pm 99$ \\
\hline Middle & $27.3 \pm 14.7$ & $2.9 \pm 2.2$ & $1.4 \pm 1.7$ & $1.6 \pm 0.9$ & $603 \pm 115$ \\
\hline Back & $27.0 \pm 13.3$ & $2.9 \pm 2.1$ & $1.4 \pm 1.8$ & $1.7 \pm 1.0$ & $599 \pm 104$ \\
\hline
\end{tabular}

Mean values of EPS (carbohydrates and protein) and chlorophyll a contents ( $n=144)$, bacterial cell counts $(n=24)$ and surface adhesiveness $(n=162)$ over all measuring dates of the experiment within all six flumes (with STDev).

related (Spearman; $\mathrm{rs}=0.69 ; n=40 ; p<0.0001$ ). Still, between days 11 and 14, the relation was negative although not significant (Spearman; rs $=-0.56 ; n=10 ; p=0.089$ ). In addition, chlorophyll $a$ values were positively related to EPS carbohydrates (Spearman; $\mathrm{rs}=0.75 ; n=120 ; p<$ 0.0001 ) as well as EPS proteins (Spearman; rs $=0.60 ; n=$ $120 ; p<0.0001)$ during the entire experiment.

\section{Microalgae community}

Intra-flume comparisons of the diatom community displayed a high proportional similarity index (PSI) from the beginning onwards that even increased over the experiment: PSI 0.71 (day 7), $0.76 \pm 0.09$ (day 14) and $0.86 \pm 0.03$ (day 22). The PSI of the inter-flume comparison was similar (e.g. $0.72 \pm 0.05$ at day 22).

While most algal species were determined sporadically in single flumes (listed in Table 4); three diatoms occurred ubiquitously in all flumes: Nitzschia fonticola, Nitzschia paleacea and Surirella brebissonii var. kuetzingii. Apparently, N. paleacea was the dominant species throughout all flumes while the other two diatoms showed varying abundances in the different flumes $(N$. fonticola dominant in flume 2 and S. brebissonii dominant in flume 4). Besides the generally prevailing diatoms, the green algae Scenedesmus sensu lato was detected within the biofilms from day 7 onwards.

\section{Bacterial community}

The biofilms' bacterial range-weighted richness (RWR) showed no significant inter-flume variations over time (one-way ANOVA; $n=20 ; p=0.9740$ ), but indicated two different stages during biofilm growth. During the first 2 weeks, the initially high (mean) RWR of the biofilms (day $541.4 \pm 9.8$ ) decreased to a medium (day $719.6 \pm$
6.0) and virtually low level (day $14 \quad 10.7 \pm 4.5$ ). In contrast, a strong increase could be detected in RWR over the last 2 weeks (day $2251.4 \pm 14.1$ ).

Generally, high values of dynamics were observed (mean rate of weekly change $31.5 \pm 8.0 \%$ ), indicating severe changes within the bacterial community. Over time, mean dynamics (rate of change) within the bacterial community increased from day 5 to day 7 (from $25.0 \pm$ 10.7 to $30.8 \pm 13.7 \%$ ), followed by a decrease until day 11 (to $25.4 \pm 10.5 \%$, Figure 3 ). Until day 14 , mean dynamics reached a new maximum $(42.9 \pm 7.5 \%)$ and decreased again subsequently (to $25.0 \pm 8.3 \%$ until day 26). The inter-flume comparison of the dynamics development pattern showed no significant differences (one-way ANOVA; $n=35 ; p=0.506$ ).

Over the experiment, the functional organization of the biofilms' bacterial community increased steadily (Figure 4) and showed no significant inter-flume difference (one-way ANOVA; $n=20 ; p=0.3910$ ): on day 5 , $20.0 \%$ of the bacterial DGGE bands corresponded to a mean proportion of $52.9 \pm 7.2 \%$ of the cumulative band abundance indicating a medium degree of functional organization. This value slightly increased until day 7 $(59.8 \pm 4.7 \%)$ and subsequently reached a high level at $73.8 \pm 10.8 \%$ on day 14 . Until day 22 and for the rest of the experiment, this increase was mitigated, but still detectable $(77.2 \pm 5.2 \%$ on day 22$)$.

\section{Biostabilization}

The developing biofilms established a surface adhesiveness which was up to four times higher than the abiotic sediment (Figure 5). This increase from $232 \pm 7 \mathrm{~mA}$ at the start of the experiment to $652 \pm 90 \mathrm{~mA}$ at day 5 was highly significant (KWT; $n=135 ; p<0.000$, days 1 to 2 ;

Table 2 Inter-flume comparison

\begin{tabular}{|c|c|c|c|c|c|}
\hline Flume & $\begin{array}{l}\text { Carbohydrates } \\
\left(\mu \mathrm{g} \mathrm{gDW}{ }^{-1}\right)\end{array}$ & $\begin{array}{l}\text { Proteins } \\
\left(\mu \mathrm{g} \mathrm{gDW} W^{-1}\right)\end{array}$ & $\begin{array}{l}\text { Chlorophyll } a \\
\left(\mu \mathrm{g} \mathrm{gDW}{ }^{-1}\right)\end{array}$ & $\begin{array}{l}\text { Bacterial cells } \\
\left(10^{7} \mathrm{gDW}^{-1}\right)\end{array}$ & $\begin{array}{l}\text { Surface adhesiveness } \\
(\mathrm{mA})\end{array}$ \\
\hline 1 & $23.1 \pm 9.9$ & $2.0 \pm 1.7$ & $1.1 \pm 1.0$ & $2.2 \pm 1.7$ & $630 \pm 107$ \\
\hline 2 & $26.5 \pm 11.2$ & $2.7 \pm 1.2$ & $1.0 \pm 1.0$ & $1.9 \pm 1.7$ & $600 \pm 96$ \\
\hline 3 & $25.5 \pm 8.2$ & $3.1 \pm 1.6$ & $1.4 \pm 1.5$ & $1.9 \pm 1.0$ & $558 \pm 91$ \\
\hline 4 & $31.0 \pm 16.5$ & $2.5 \pm 2.0$ & $1.6 \pm 2.1$ & $2.0 \pm 1.4$ & $623 \pm 132$ \\
\hline 5 & $32.7 \pm 18.0$ & $3.4 \pm 3.0$ & $2.1 \pm 2.5$ & $1.5 \pm 0.9$ & $623 \pm 88$ \\
\hline
\end{tabular}

Mean values of EPS (carbohydrates and protein) and chlorophyll a contents ( $n=120)$, bacterial cell counts ( $n=40)$ and surface adhesiveness ( $n=135)$ over all measuring dates of the experiment within all five flumes (with STDev). 
Table 3 Results of the Kruskall-Wallis tests

\begin{tabular}{lllll}
\hline Comparison & Carbohydrates & Proteins & Chlorophyll $\boldsymbol{a}$ & Bacterial cells \\
\hline Intra-flume & $p=0.8203\left(n=144^{\mathrm{a}}\right)$ & $p=0.5865(n=144)$ & $p=0.9492(n=144)$ & $p=0.8540\left(n=24^{\mathrm{b}}\right)$ \\
Inter-flume & $p=0.3364\left(n=120^{\mathrm{d}}\right)$ & $p=0.1223(n=120)$ & $p=0.5432(n=120)$ & $p=0.9522\left(n=40^{\mathrm{e}}\right)$
\end{tabular}

Intra-flume and inter-flume comparisons of the measured data. ${ }^{a} 3$ regions $\times 6$ flumes $\times 8$ sampling points; ${ }^{b} 3$ regions $\times 1$ flume $\times 8$ sampling points; ${ }^{c} 3$ regions $\times 6$ flumes $\times 9$ sampling points (incl. blanks); ${ }^{d} 3$ regions $\times 5$ flumes $\times 8$ sampling points; ${ }^{\text {e }} 1$ region (middle) $\times 5$ flumes $\times 8$ sampling points; ${ }_{3} 3$ regions $\times 5$ flumes $\times 9$ sampling points.

$p=0.0131$, days 2 to 5 ). After a decline between days 5 and 7, new maximum values up to $956 \mathrm{~mA}$ were measured on day 11 , with a mean value of $684 \pm 119 \mathrm{~mA}$. Subsequently, adhesiveness slightly decreased and stagnated at a level of ca. $607 \pm 89 \mathrm{~mA}$ for the rest of the experiment.

\section{Discussion}

Biofilm growth within the new sophisticated mesocosm

The main purpose of the present study was to test this new design of straight flumes in terms of nature-like biofilm settlement and cultivation. Despite the absolutely identical setup of the six flumes, biofilm development could still differ due to smallest, possibly undetected variations in, e.g. the flow field. Moreover, biofilm growth is per se characterized by spatial heterogeneity. Thus, for the new flume design, it remained to be shown whether deviations in biofilm growth increase strongly along the test sections of one flume or between the individual flumes. This is very important since the comparability of biofilm growth and composition in the different straight flumes as well as within different flume regions is an essential prerequisite for further studies on the impact of environmental parameters on biofilm ecology and functionality.

The high spatial heterogeneity in biofilms and their complex mutual interactions with the environment have been described manifold (e.g. [19-21]). Biofilms have even been described as microbial landscapes that not only are shaped in their spatial configuration by multiple physico-chemical factors but also alter their environment in considerable dimensions due to their growth [22]. Thus, not surprisingly, biofilms settling in the flumes exhibited high small-scale heterogeneity (on a single cartridge), but these pattern were clearly similar in all flume regions and flumes. This reflects the exact same settings of temperature, illumination and, most importantly, hydrodynamics in all flumes to provide the same settling and growth conditions for biofilms. Most common, an integral approach (Reynolds) is applied to account for the flow conditions within a flume as a precisely controlled hydrodynamic regime is either not necessary or not practicable. However, an exact determination of near-bed turbulences and bed shear stress directly at the sites of interest is essential for this study because various boundary effects such as eddy developments along the walls of a flume may influence hydrodynamics and near-bed turbulence significantly. Consequently, this might impact the erosive forces acting on biofilms as well as their nutrient replenishment to affect biofilm morphology and activity. Hence, in this study, the turbulence distribution was determined via high-resolution laser Doppler anemometry (LDA) before this experiment and later on checked with acoustic Doppler velocimetry (ADV) [17]. In addition, the long inlet flow section as well as the design of
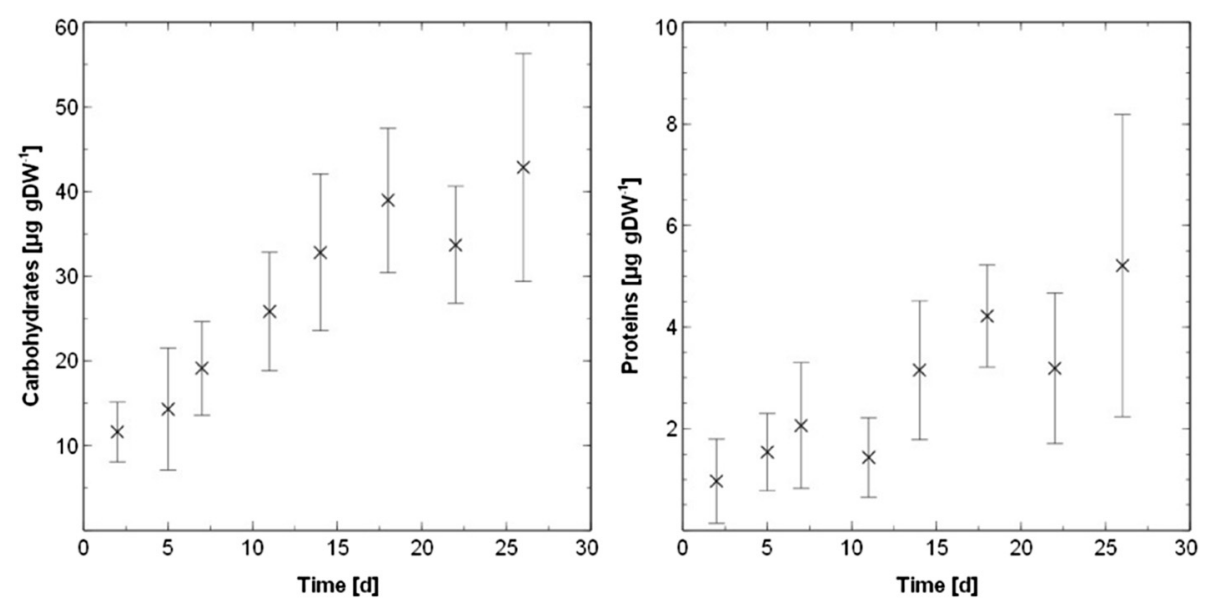

Figure 1 Compounds of the colloidal EPS fraction (determined via spectral photometry). Left: mean carbohydrate contents; right: mean protein contents (for both $n=15$; with STDev). 

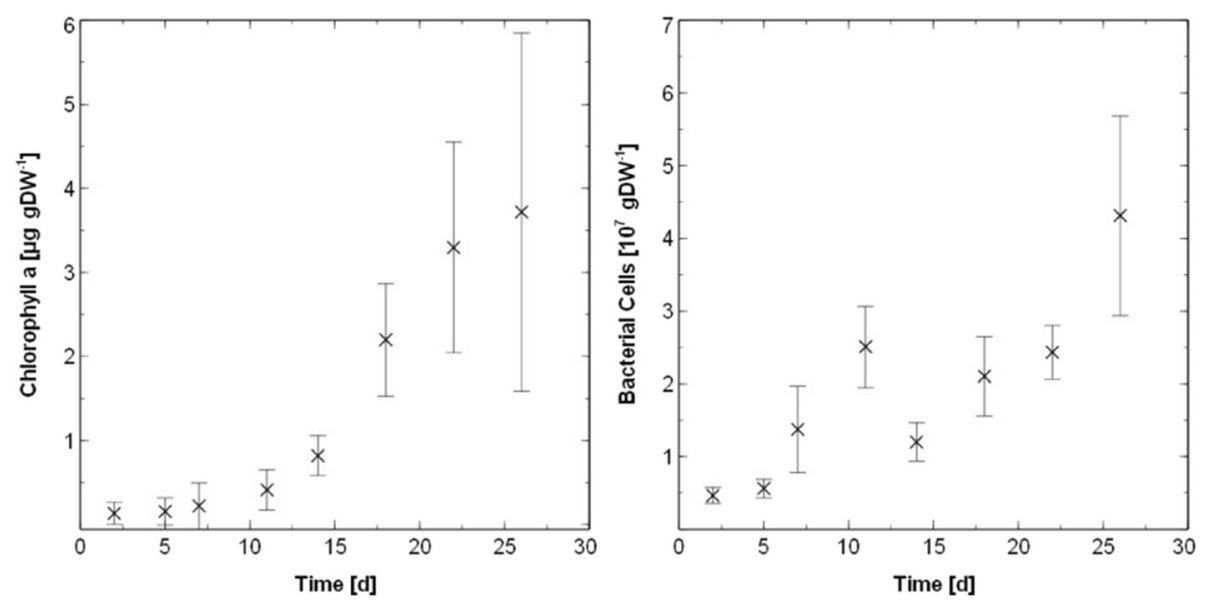

Figure 2 Microbial biomass of the biofilms. Left: mean chlorophyll a contents ( $n=15$; with STDev) (determined via spectral photometry); Right: mean bacterial cell counts ( $n=5$; with STDev) (determined via epi fluorescence microscopy).

the flumes (with a sufficient distance of the biofilm cartridges to the flume walls) ensures a homogenous turbulence distribution over the biofilm growth section. Another essential fact to keep in mind is that bed shear stress is an exponential function of the flow velocity emphasizing the importance of constant discharges within the flumes. This is why high-resolution discharge measurements were performed in all flumes throughout the experiment. These data gave evidence on the constant and similar discharges in all six flumes and thus on the identical bed shear stress levels over all biofilm growth sections in the presented experiment. This is one important prerequisite for the high

Table 4 Algae species of the mature biofilms (22nd day)

\begin{tabular}{|c|c|c|c|c|c|}
\hline & \multicolumn{5}{|c|}{ Flume no. } \\
\hline & 1 & 2 & 3 & 4 & 5 \\
\hline Cyclotella menighiana & - & 3.8 & - & 3.0 & - \\
\hline Fragilaria construens $f$. venter & - & - & 3.0 & - & - \\
\hline Myamaea atomus var. permitis & - & - & 3.6 & - & - \\
\hline Navicula capitatoradiata & - & 3.5 & - & - & - \\
\hline Navicula reichardtiana & - & 2.0 & 2.1 & - & - \\
\hline Nitzschia abbreviata & - & 2.6 & - & - & - \\
\hline Nitzschia acicularis & 2.1 & - & - & - & - \\
\hline Nitzschia fonticola & 11.2 & 21.9 & 8.9 & 4.5 & 6.1 \\
\hline Nitzschia fonticola - romana form & 2.9 & 10.5 & 5.6 & - & 3.4 \\
\hline Nitzschia palea var. debilis & 6.6 & - & - & - & - \\
\hline Nitzschia palea var. palea & 4.1 & 2.0 & - & 2.7 & - \\
\hline Nitzschia paleacea & 48.5 & 37.0 & 61.4 & 54.5 & 69.2 \\
\hline Stephanodiscus sp. & 3.7 & - & - & - & - \\
\hline Surirella brebissonii var. kuetzingii & 2.9 & 3.5 & 3.0 & 26.9 & 9.8 \\
\hline Others & 17.8 & 13.1 & 12.5 & 8.4 & 11.6 \\
\hline
\end{tabular}

Proportional abundances of algal species [\%]; species with a relative abundance of less than $2.0 \%$ were added up and summarized as 'others'. reproducibility of biofilm cultivation that could be shown for the new experimental setup in this study.

\section{Biomass and EPS}

Several studies investigating intertidal biofilms suggested a complex non-linear relationship between microbial biomass and EPS production [23-25]. The occasionally fast shifting nutritional and physiological states of the biofilm microbes might be of major importance for EPS production and secretion. This was underpinned by Underwood et al. [26] who described that diatom EPS production was, among others, dependent on the nutritional condition of the cells. The natural riverine water used in the flumes contained moderate nutrient concentrations comparable to oligotrophic habitats that remained stable over the experiment. Besemer et al. [27] and Artigas et al. [12] reported microbial biomass similar to the values determined in the present experiment under comparable conditions of nutrient availability (e.g. bacterial cell densities up to $1.13 \times 10^{8}$ cells cm$~^{-2}$ or chlorophyll $a$ concentrations of 0.03 to $6.28 \mu \mathrm{g} \mathrm{cm}^{-2}$ ). In contrast, biofilms in a eutrophic river (Neckar) were characterized by high microbial biomass and EPS production [28], e.g. an up to 16-fold higher chlorophyll $a$ content than in this study emphasizing the effects of different water qualities upon biofilm development, corresponding metabolic rates and possibly, functionality. Low supply of nutrients may have restricted EPS production during biofilm development in the present experiment; still, the biostabilization effect (as discussed later) was impressive.

\section{Microbial community}

As Marzorati et al. [29] stated, RWR, dynamics and functional organization calculated from the DGGE fingerprints should be seen as qualitative indicators, not as absolute measures due to the known drawbacks of molecular 

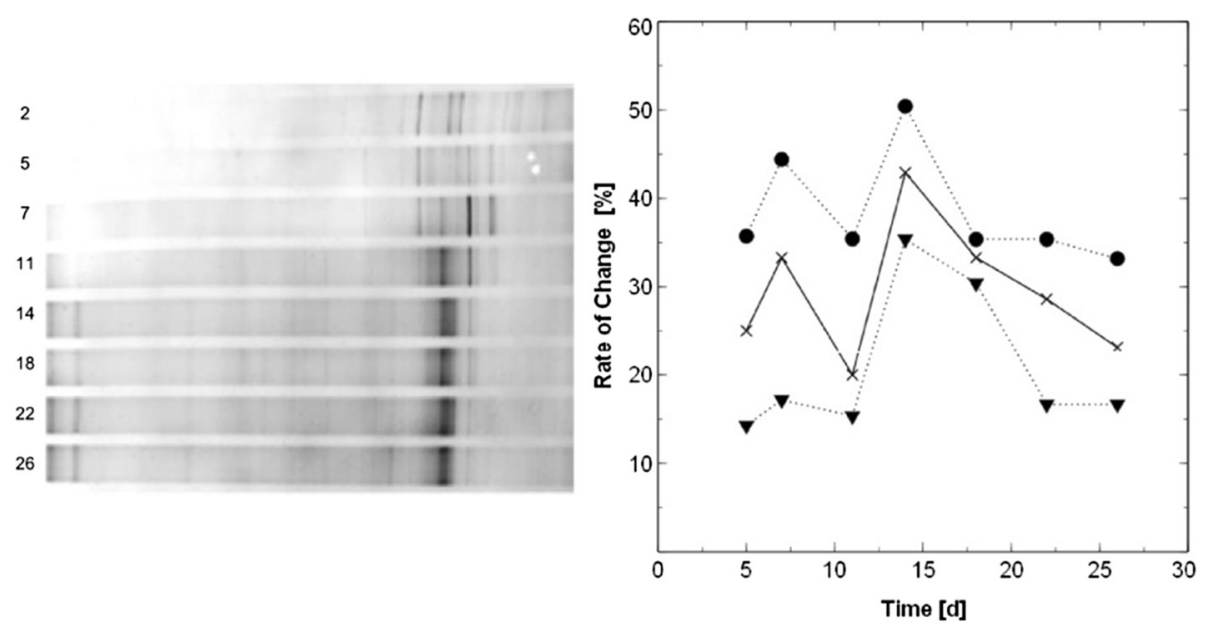

Figure 3 Dynamics within the bacterial community. Left: DGGE band patterns of 165 rDNA gene diversity of biofilms exemplified shown for flume 1 (stained with ethidium bromide; inverted picture; numbers represent days of growth); Right: moving window analysis of the bacterial community's dynamics in the same flume (crosses) based on densitometry similarity matrices. Additionally shown are the maximal (round dots) and minimal (triangular) change rates over the residual flumes.

fingerprinting techniques. Nevertheless, they are an important tool to describe, compare and interpret different DGGE band patterns in order to obtain a higher level of information about ecological processes in biofilms. Generally, observing the microbial community of biofilms in this study revealed two distinct stages during development. The first phase could be described as an initial colonization of the abiotic substrate by planktonic bacteria. The findings of Beier et al. [30] or Crump and Hobbie [31], e.g. 40 bacterial TGGE bands in comparable riverine

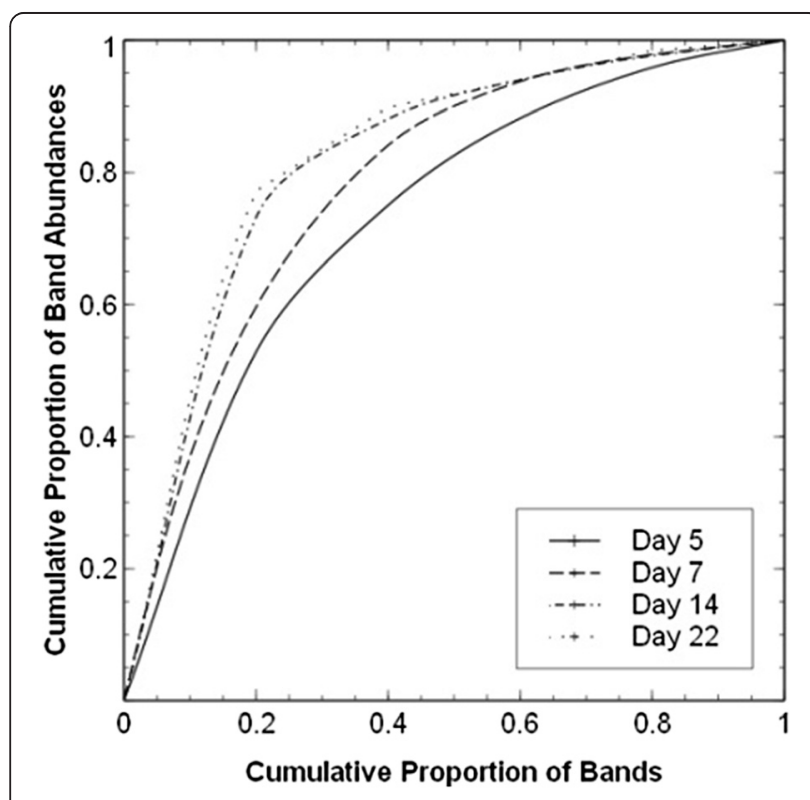

Figure 4 Functional organization of bacterial community expressed as Parento-Lorenz curves obtained via densitometry and normalization of DGGE peak patterns. water, support the initially high bacterial RWR in this experiment. During the subsequent establishment of a bacterial biofilm within the first 11 days, competition and specialization of the bacterial community became visible by decreasing RWR and increasing functional organization. Manz et al. [32] and Araya et al. [33] described similar shifts within the bacterial community composition during the formation of lotic biofilms. In the period between days 11 and 14, severe changes within the bacterial community could be observed. Along with significantly decreasing cell

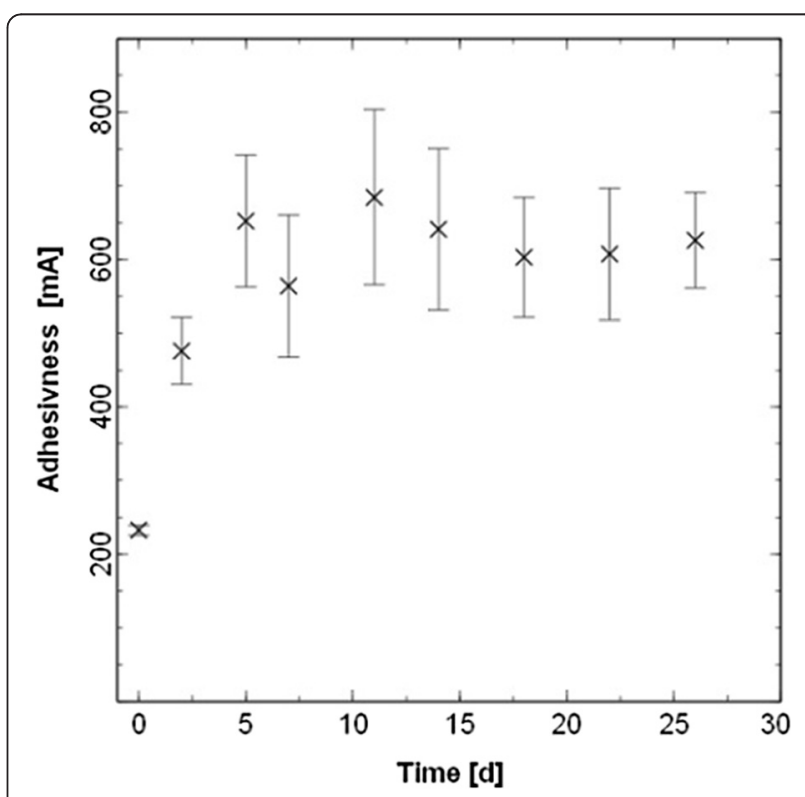

Figure 5 Development of the biofilms' adhesiveness displayed as mean determined current ( $n=15$; with STDev) during MagPI measurement. 
counts and RWR, increasing dynamics and functional organization of the bacteria might be due to bacterial biofilm detachment, the initial algal colonization or settlement of grazing ciliates as described by Wey et al. [34] - or a combination of these processes.

Besemer et al. [27] highlighted the role of diatoms as key players in river biofilms as they shape the bacterial community in a combination of physical and biological processes. The importance of diatoms in this experiment became obvious since parallel to the development of the diatom community (from day $14 \mathrm{on}$ ), a steady increase of vertical and horizontal heterogeneity of the biofilms could be visually observed. As described by Besemer et al. [16], this spatial small-scale heterogeneity was a major driver affecting the development of the microbial community. Thus, diatoms apparently influenced the bacterial community in different ways. On one hand, their photosynthetic activity and EPS production may have supported the growth of associated bacteria as indicated by high increase rates of the total cell counts after day 14 of the experiment, a phenomenon already described by Espeland $e t$ al. [35]. On the other hand, the pronounced three-dimensional structures of their colonies may have allowed the formation of various physical and biochemical transition/gradient zones, e.g. $\mathrm{O}_{2}$ gradients as described by Glud et al. [36] or Fenchel and Glud [37]. Due to this formation of many microenvironments, accumulation of different metabolic products of the diatoms as well as their associated bacteria in the biofilm matrix and several metabolic cascades, various niches can develop for a broad range of bacteria with different physiologies [38]. In this context, specialized bacteria may have found optimal conditions in the matured biofilms as reported by Manz et al. [32]. Summarizing, the diatom development apparently led to dominance of a few bacterial species but may also have led to the establishment of various niches where diverse bacterial species might occur in low abundances, indicated by steadily decreasing dynamics within the bacterial community and parallel increasing bacterial RWR.

\section{Biostabilization}

Due to its high economic and ecological importance, sediment dynamics in lotic systems plays a major role in hydraulic engineering. Different modelling approaches approximated the highly complex sediment-water system. Briefly, the Shields model [39] is commonly applied to determine the stability of sediments versus erosional forces by defining characteristic diameters and the density of the sediment grains. However, this approach is not applicable for sediments with strong biological influence. Righetti et al. [40] described the first model based on the Shields equation introducing adhesiveness/adhesion as a new parameter in order to incorporate the influence of biofilms on sediment stability. Finally due to the development of the MagPI device that has been applied successfully in the marine habitat $[6,7,41]$, the determination of biological-induced adhesiveness could be achieved at high temporal and spatial resolution. While most studies focused on brackish/intertidal areas (e.g. $[23,42,43]$ ), up to now, biostabilization of lotic fine sediments is virtually unaddressed. Spears et al. [44] suggested the major importance of biostabilization in marine/brackish habitats supporting the current doctrine that high quantities of strong ionic bounds significantly strengthen the EPS matrix. Nevertheless, despite observing significantly lower EPS values as well as microbial biomass (as compared to brackish/marine biofilms), a significant biostabilization effect was detected. This emphasized the importance of biofilm-induced stabilization of fine sediments in lotic waters (and contradicted the current doctrine).

Furthermore, this study gave insights in the development of various geochemical and (micro-) biological parameters during biofilm growth affecting this important ecosystem function. In this context, the content of colloidal EPS compounds could be seen as an approximate marker for biostabilization capacity. Further investigation of the quality of these polymers could lead to the identification of single carbohydrate or protein moieties with high gluing and stabilizing capability. While biofilm stability appeared to be related to total cell counts in nascent biofilm stages, the development of the bacterial community composition turned out to be even more crucial. Thereby, short and long-term shifts within the bacterial and algal community occurred simultaneously to significantly change biofilm stability. This emphasizes the importance of the molecular biology tools used in this study to address biofilm composition and diversity. Identification of bacterial key players in biostabilization and their interactions with algae could be the next step to further elucidate the contribution of microbiology to sediment stability. Future studies should also consider the role of the protozoa community in shaping microbial biofilm community and functionality, here biostabilization.

\section{Conclusions}

The stabilizing effect of biofilms upon lotic fine sediment is currently unaddressed despite its broad range of economic and ecological implications. To investigate the complex interactions between the biofilm and its environment, a sophisticated and unique setup was designed combining biological and engineering expertise.

The evaluation of biofilm growth in these new flumes is presented in this paper to demonstrate that comparable biofilms (intra- and inter-flume wise) could be cultivated while exposed to the same abiotic environment. Furthermore, the biofilm cultivation under strictly controlled boundary conditions gave evidence on the 
importance of biostabilization (known to be substantial in intertidal mudflats) within lotic fine sediments. In doing so, first insights into various ecological processes which shape the microbial community and impact the overall biofilm functionality could be gained; for instance, the change of a bacteria-dominated nascent biofilm to a diatom-dominated matured development stage resulted in biofilms which stabilized the underlying sediment significantly.

Summarizing, regarding their biological and biochemical features, representative biofilms can be grown in this novel system - an essential prerequisite for further research into natural biofilm colonization and development. In particular, the mutual interactions of various environmental parameters impacting biofilms can now be addressed and reliably related to each other. With the link to biofilm functionality, the significance of biostabilization can thus be investigated for different niches in freshwater habitats.

\section{Methods}

\section{Experimental setup and sampling}

Biofilms grew in six flumes, each with an individual, separate water circuit (see Thom et al. [45] and Figure 6) under constant natural-like environmental conditions. Briefly, the flumes (length $\times$ width $\times$ height, $3.00 \mathrm{~m} \times$ $0.15 \mathrm{~m} \times 0.15 \mathrm{~m}$ ) were designed to allow a homogeneous flow field and constant shear stress across the biofilm cultivation section (length $1.00 \mathrm{~m}$ ). This section contained 12 substratum cartridges (length $\times$ width $\times$ height, $0.08 \mathrm{~m} \times$ $0.06 \mathrm{~m} \times 0.02 \mathrm{~m}$ ) that could be transferred outside the flume for further measurements. Cartridges were illuminated by two parallel fluorescent tubes (Osram Biolux; 480 to $665 \mathrm{~nm}$ ) and homogenous irradiation was confirmed by measurements of light intensity and wavelength irradiance of the photosynthetic active radiation (PAR) spectrum using a high-resolution spectroradiometer (SR-9910, Macam Photometric Ltd., Livingston, Scotland) as described by
Gerbersdorf and Schubert [46]. Discharge was set at $0.80 \pm 0.10 \mathrm{~L} \mathrm{~s}^{-1}$ by adjusting the by-pass (flow velocity $0.07 \pm 0.01 \mathrm{~m} \mathrm{~s}^{-1}$ within each flume) and continuous measured with an installed mini-flow meter (Bürkert 8030, Ingelfingen, Germany). Fluvial water was retrieved from the middle reach of the River Enz (BadenWürttemberg, Germany). While adjusted to constant temperature $\left(15^{\circ} \mathrm{C} \pm 0.3^{\circ} \mathrm{C}\right)$ by a cooling water circuit, $200 \mathrm{~L}$ were circulated in each flume by a circulatory pump (BADU Eco Touch, Speck Pumpen, Neunkirchen am Sand, Germany) for 4 weeks (1 August 2012 to 28 August 2012). Thus, indigenous microorganisms within the river water settled the cartridges filled with inert glass beads (diameter 100 to $200 \mu \mathrm{m}$ ) eventually forming a biofilm. Sampling of each flume was performed on the days $2,5,7,11,14,18,22$ and 26 . One litre of water was withdrawn for subsequent nutrient analysis. The 12 substratum cartridges of each flume were classified in three regions 'front', 'middle' and 'back' of four consecutive cartridges each. At each sampling, ten samples of $0.5 \mathrm{~cm}^{3}$ were randomly withdrawn from the sediment of each flume regions by a cut-off syringe and pooled. Subsamples $\left(0.5 \mathrm{~cm}^{3}\right)$ were transferred into Eppendorf tubes for further analyses. Due to pump failure and flow stagnation in the sixth flume during the first week, this flume was excluded from inter-flume comparison.

\section{Water chemistry, EPS and bacterial cell counts}

Water samples were analysed according to DIN EN ISO 10304 and using a quick test (Hach Lange GmbH, Berlin, Germany) based on DIN 38406-E5-1: the concentrations of fluoride, chloride, nitrate, ammonia, sulphate and phosphate ions were quantified. The colloidal (water-extractable) EPS fractions of the biofilms were extracted according to Gerbersdorf et al. [47]. Afterwards, carbohydrates and protein contents were determined by phenol assay and modified Lowry procedure,

(g)

(k)
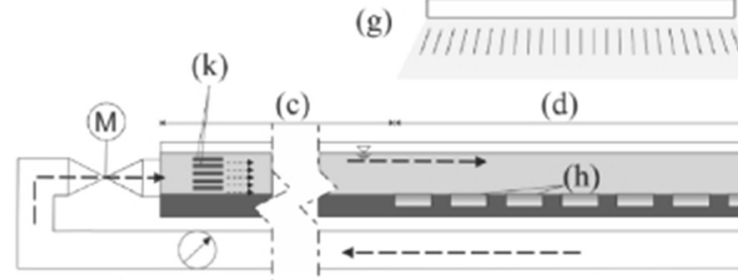

(a) Outflow tank

(b) Pump

(c) Inlet flow section

(d) Test section

(e) Outlet flow section

(e).

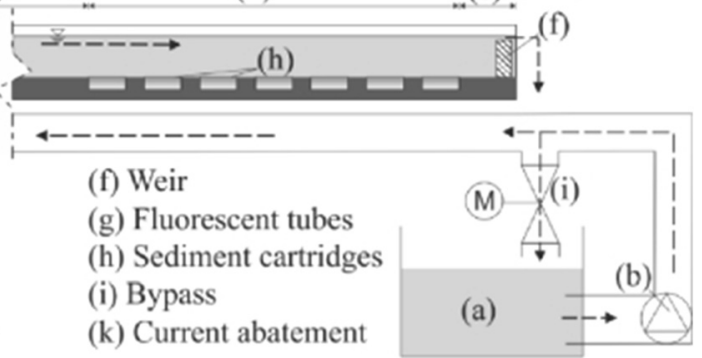

Figure 6 Scheme of a single straight flume. The glass channel (length $\times$ width $\times$ height, $3.00 \mathrm{~m} \times 0.15 \mathrm{~m} \times 0.15 \mathrm{~m}$ ) contained an inlet flow section (c) $(2.00 \mathrm{~m})$ and a biofilm cultivation section (d) $(1.00 \mathrm{~m})$. 
respectively [48-50]. Chlorophyll a/pheophytin were measured by ethanol extraction before and after acidification, respectively (DIN 38 412/16). Bacterial cell counts were performed in the three regions of flume 4 (intra-flume comparison) as well as in the middle regions of the flumes 1, 2, 3 and 5 (inter-flume comparison) on the eight sampling points of the experiment. Samples were fixed with $4 \%$ paraformaldehyde (final concentration) and shaken horizontally for 15 min to be treated afterwards ( 5 pulses à $5 \mathrm{~s}$ at $20 \%$ intensity) with a Sonopuls UW 3100 ultrasonic probe (Bandelin electronic, Berlin, Germany). After a settlement period for $1 \mathrm{~min}$, subsamples of $99 \mu \mathrm{L}$ were taken from the supernatant. Suspended cells were stained with $1 \mu \mathrm{L}$ SYTO $13(500 \mu \mathrm{M})$ (Life Technologies, Carlsbad, CA, USA) for $15 \mathrm{~min}$ and counted at $488 \mathrm{~nm}$ excitation using an Axioscop fluorescence microscope (Carl Zeiss, Oberkochen, Germany).

\section{Algal community composition}

To investigate inter-flume heterogeneity, samples fixed with Lugol solution (2\%) were analysed from the middle region of the flumes 1 to 5 at day 22. For the intra-flume comparison, samples from all three regions of flume 3 were investigated at days 7,14 , and 22 . All samples were separated in two subsamples; one was used for direct microscopic cell counts by Axioscope A1 microscope (Carl Zeiss, Oberkochen, Germany). The other was further treated to remove organic matter and embedded in order to determine diatom species by their frustules [51-53]. The data functioned as basis for further calculations on the PSIs of the algal communities [54].

\section{Bacterial community composition}

DNA was isolated using the Nucleospin Kit for Soil (Macherey and Nagel, Düren, Germany) according to the manufacturer's information. A PCR assay was conducted using the universal bacterial 16S rRNA gene primers 27f (5'-AGA GTT TGA TCM TGG CTC AG$3^{\prime}$ ) and 517r (5'-ATT ACC GCG GCT GCT GG-3') $[55,56]$. The forward primer had an attached GC-clamp (5'-CGC CCG CCG CGC CCC GCG CCC GTC CCG CCG CCG CCC CCG CCC C-3') for subsequent DGGE (Denaturing Gradient Gel Electrophoresis). Each reaction $(25 \mu \mathrm{L})$ contained 15 to 20 ng DNA, $0.125 \mu \mathrm{L}$ dNTPs $(200 \mu \mathrm{M}), 0.25 \mu \mathrm{L}$ of each primer $(40 \mu \mathrm{M})$, $0.13 \mu \mathrm{L}$ Taq DNA polymerase (HotStart ${ }^{\text {tu }}$ Polymerase, 5 $\mathrm{U} / \mu \mathrm{L}$, QIAGEN, Venlo, Netherlands), $2.5 \mu \mathrm{L} \times 10 \mathrm{PCR}$ buffer (QIAGEN, Venlo, Netherlands) provided by the enzyme manufacturer and $16.38 \mu \mathrm{L}$ sterile PCR water (Merck Millipore, Darmstadt, Germany). Amplification was performed with a GeneAmp PCR system 9700 (Applied Biosystems, Carlsbad, CA, USA) as follows: $30 \mathrm{~s}$ at $94^{\circ} \mathrm{C}, 35$ cycles of $30 \mathrm{~s}$ at $94^{\circ} \mathrm{C}, 30 \mathrm{~s}$ at $55^{\circ} \mathrm{C}$ and $60 \mathrm{~s}$ at $72^{\circ} \mathrm{C}$, followed by a final extension of $7 \mathrm{~min}$ at $72^{\circ} \mathrm{C}$. The PCR products were loaded onto $1 \%$ agarose gels in $\times 1$ TAE buffer ( $\mathrm{pH}$ 8.0), ethidium-bromidestained and studied under UV illumination $(600 \mathrm{~nm})$.

DGGE was performed with a Bio Rad DCode (Bio-Rad Laboratories, Hercules, CA, USA) system as described by Muyzer et al. [57]: PCR products of similar size were loaded on a 1.5 -mm-thick, vertical gel containing $7.5 \%$ $(w / v)$ polyacrylamide (37.5:1 acrylamide/bisacrylamide) with a linear denaturing gradient of urea and formamide (40 to 70\%). Electrophoresis was performed in a $\times 1 \mathrm{TAE}$ buffer (pH 8.5) for $17 \mathrm{~h}$ at $70 \mathrm{~V}$ and $56^{\circ} \mathrm{C}$. Gels were stained with SYBR Gold (Invitrogen, Karlsruhe, Germany) for 15 min and analysed using a Lumi-Imager F1 Working Station (Roche Diagnostics, Mannheim, Germany). An image of each gel was taken with a CCD camera system (The Imager, Appligene, Illkirch, France), and the software Lumi Analyst 3.1. DGGE banding patterns were analysed with the program GelCompar II (6.0) and processed with ImageJ (148 a) and DiGit (Kramer 2013, personal communication). RWR, community dynamics and functional organization were calculated according to Marzorati et al. [29].

\section{Surface adhesiveness}

Biofilm adhesiveness - a measure for biostabilization capacity - was determined with a modified magnetic particle induction (MagPI) system (Figure 6), e.g. using an improved electromagnetic inductor containing a highly magnetisable $\mu$ metal core with low remanence. Briefly, ferromagnetic particles were spread on the biofilm surface and the electromagnet was set up vertically in a defined distance of $0.4 \mathrm{~cm}$ to the surface. The strength of the magnetic field needed to retrieve the particles from the surface is equivalent to its adhesiveness. The magnetic field can be calculated from the current (amperage) via calibration of the used electromagnet.

\section{Statistics}

Statistics were conducted using the software Analyze-it225 (1.0.5.0.): Shapiro-Wilks tests (confidence interval 95\%) were performed to check normal distribution of the data sets. In case of normally distributed data, a one-way ANOVA (confidence interval 95\%; chi-square approximation) was conducted; otherwise, a Kruskal-Wallis test (KWT) (chi-square approximation; Bernoulli correction for ties) was performed to compare the different groups. To test correlation of different parameters, Spearman's rank correlation coefficients were calculated.

\section{Abbreviations}

ANOVA: analysis of variance; BCC: bacterial cell counts; ca.: circa; ${ }^{\circ} \mathrm{C}$ : degree Celsius; DIN EN ISO: Deutsche Industrie Norm Europäische Norm International Organization for Standardization; DGGE: denaturing gradient gel electrophoresis; DNA: deoxyribonucleic acid; DW: dry weight; h: hour; KWT: Kruskal-Wallis test; mA: milliampere; $\mathrm{mT}$ : millitesla; min: minute; $\mu \mathrm{M}$ : micromolar; $\mu \mathrm{L}$ : microliter; ng: nanogram; PAR: photosynthetic active radiation; PCR: polymerase chain reaction; rDNA: ribosomal DNA; resp: respectively; RWR: range-weighted richness; S: Svedberg; s: seconds; STDev: standard deviation; TAE: tris acetic acid EDTA; UV: ultraviolet; V: volt; $w / v$ : weight to volume. 


\section{Competing interests}

The authors declare that they have no competing interests.

\section{Authors' contributions}

HS compiled and analysed the biochemical, biological and molecular biology data. MT performed the adhesiveness measurements. KM, UO and SB supported the molecular biology analysis and data computation. SW and SUG headed the investigation. HS and SUG developed the experimental design and wrote the manuscript. The final manuscript was read and approved by all authors.

\section{Acknowledgements}

The authors are grateful to the DFG (Deutsche Forschungsgemeinschaft) for financing the project 'Ecosystem Engineering: Sediment entrainment and flocculation mediated by microbial produced extracellular polymeric substances (EPS)' (GZ: GE 1932/3-1). We thank for the excellent support of the molecular analyses at the Institute of Functional Interfaces, Karlsruhe Institute of Technology (KIT) (Prof. U. Obst) and at the Centre for Applied Geosciences (ZAG), University Tübingen (Prof. A. Kappler). The authors much appreciate the cooperation with Dr. M. Schweikert, Institute of Zoology, University Stuttgart to get access to the Microscopic Facility.

\section{Author details}

${ }^{1}$ Institute for Modelling Hydraulic and Environmental Systems, University Stuttgart, Pfaffenwaldring 61, 70569 Stuttgart, Germany. ${ }^{2}$ Institute of Functional Interfaces, Karlsruhe Institute of Technology (KIT), Hermann-von-Helmholtz-Platz 1, 76344 Eggenstein-Leopoldshafen, Germany. ${ }^{3}$ Geomicrobiology/ Microbial Ecology, Centre for Applied Geosciences (ZAG), Eberhard-Karls-University Tübingen, Sigwartstrasse 10, 72076 Tübingen, Germany.

\section{Received: 10 November 2014 Accepted: 22 December 2014} Published online: 14 January 2015

\section{References}

1. Underwood GJC, Paterson DM. Seasonal changes in diatom biomass, sediment stability and biogenic stabilization in the Severn Estuary. J Mar Biol Assoc UK. 1993:73:871-87.

2. Tolhurst J, Gust G, Paterson D. The influence of an extracellular polymeric substance (EPS) on cohesive sediment stability. In: Winterwerp JC, Kranenburg C, editors. Fine Sediment Dynamics in the Marine Environment. Amsterdam: Proceedings in Marine Science 5; 2002. p. 409-25.

3. Karickhoff SW, Brown DS, Scott TA. Sorption of hydrophobic pollutants on natural sediments. Water Res. 1979;13:241-8.

4. Audry S, Schafer J, Blanc G, Jouanneau JM. Fifty-year sedimentary record of heavy metal pollution ( $\mathrm{Cd}, \mathrm{Zn}, \mathrm{Cu}, \mathrm{Pb})$ in the Lot River reservoirs (France). Environ Pollut. 2004;132:413-26.

5. Cuadrado DG, Carmona NB, Bournod C. Biostabilization of sediments by microbial mats in a temperate siliciclastic tidal flat, Bahia Blanca estuary (Argentina). Sediment Geol. 2011;237:95-101.

6. Larson F, Lubarsky H, Gerbersdorf SU, Paterson DM. Surface adhesion measurements in aquatic biofilms using magnetic particle induction: MagPI. Limnol Oceanogr Methods. 2009;7:490-7.

7. Lubarsky $\mathrm{H}$. The impact of microbial extracellular polymeric substances on sediment stability. Doctoral dissertation, University of St Andrews. 2011.

8. Chavant P, Martinie B, Meylheuc T, Bellon-Fontaine MN, Hebraud M. Listeria monocytogenes LO28: surface physicochemical properties and ability to form biofilms at different temperatures and growth phases. Appl Environ Microbiol. 2002;68:728-37.

9. Shrout JD, Chopp DL, Just CL, Hentzer M, Givskov M, Parsek MR. The impact of quorum sensing and swarming motility on Pseudomonas aeruginosa biofilm formation is nutritionally conditional. Mol Microbiol. 2006;62:1264-77.

10. Rogers J, Dowsett AB, Dennis PJ, Lee JV, Keevil CW. Influence of temperature and plumbing material selection on biofilm formation and growth of Legionella pneumophila in a model potable water system containing complex microbial flora. Appl Environ Microbiol. 1994;60:1585-92.

11. Lemon KP, Higgins DE, Kolter R. Flagellar motility is critical for Listeria monocytogenes biofilm formation. J Bacteriol. 2007;189:4418-24.

12. Artigas J, Fund K, Kirchen S, Morin S, Obst U, Romani AM, et al. Patterns of biofilm formation in two streams from different bioclimatic regions: analysis of microbial community structure and metabolism. Hydrobiologia. 2012;695:83-96
13. McKew BA, Taylor JD, McGenity TJ, Underwood GJC. Resistance and resilience of benthic biofilm communities from a temperate saltmarsh to desiccation and rewetting. ISME J. 2011;5:30-41.

14. Battin TJ, Kaplan LA, Newbold JD, Hansen CME. Contributions of microbial biofilms to ecosystem processes in stream mesocosms. Nature. 2003;426:439-42.

15. Singer G, Besemer K, Hoedl I, Chlup A, Hochedlinger G, Stadler P, et al. Microcosm design and evaluation to study stream microbial biofilms. Limnol Oceanogr Methods. 2006;4:436-47.

16. Besemer K, Hoedl I, Singer G, Battin TJ. Architectural differentiation reflects bacterial community structure in stream biofilms. ISME J. 2009;3:1318-24.

17. Thom M, Schmidt H, Wieprecht S, Gerbersdorf S. Dimensionierung von Fließrinnen zum Aufwuchs von Biofilm unter definierten hydraulischen Randbedingungen. DGL-Jahrestagung (24. - 28. September 2012, Koblenz); 2012.

18. Länderarbeitsgemeinschaft Wasser. Beurteilung der Wasserbeschaffenheit von Fließgewässern in der Bundesrepublik Deutschland - Chemische Gewässergüteklassifikation. Berlin: LAWA; 1998.

19. Donlan RM. Biofilms: microbial life on surfaces. Emerg Infect Dis. 2002;8:881-90.

20. Wimpenny J, Manz W, Szewzyk U. Heterogeneity in biofilms. FEMS Microbiol Rev. 2000;24:661-71.

21. Bernard CS, Giraud C, Spagnolo J, de Bentzmann S. Biofilms: the secret story of microbial communities. In: Locht C, Simonet M, editors. Bacterial pathogenesis: molecular and cellular mechanisms. Caister Academic Press; 2012. p. 129-68.

22. Battin TJ, Sloan WT, Kjelleberg S, Daims H, Head IM, Curtis TP, et al. Microbial landscapes: new paths to biofilm research. Nat Rev Microbiol. 2007:5:76-81.

23. Yallop ML, Paterson DM, Wellsbury P. Interrelationships between rates of microbial production, exopolymer production, microbial biomass, and sediment stability in biofilms of intertidal sediments. Microb Ecol. 2000;39:116-27.

24. Smith DJ, Underwood GJC. The production of extracellular carbohydrates by estuarine benthic diatoms: the effects of growth phase and light and dark treatment. J Phycol. 2000;36:321-33.

25. Hanlon ARM, Bellinger B, Haynes K, Xiao G, Hofmann TA, Gretz MR, et al. Dynamics of extracellular polymeric substance (EPS) production and loss in an estuarine, diatom-dominated, microalgal biofilm over a tidal emersionimmersion period. Limnol Oceanogr. 2006;51:79-93.

26. Underwood GJC, Boulcott M, Raines CA, Waldron K. Environmental effects on exopolymer production by marine benthic diatoms: dynamics, changes in composition, and pathways of production. J Phycol. 2004;40:293-304.

27. Besemer K, Singer G, Limberger R, Chlup A-K, Hochedlinger G, Hoedl I, et al. Biophysical controls on community succession in stream biofilms. Appl Environ Microbiol. 2007;73:4966-74.

28. Gerbersdorf SU, Jancke T, Westrich B, Paterson DM. Microbial stabilization of riverine sediments by extracellular polymeric substances. Geobiology. 2008;6:57-69.

29. Marzorati M, Wittebolle L, Boon N, Daffonchio D, Verstraete W. How to get more out of molecular fingerprints: practical tools for microbial ecology. Environ Microbiol. 2008;10:1571-81.

30. Beier S, Witzel K-P, Marxsen J. Bacterial community composition in central European running waters examined by temperature gradient gel electrophoresis and sequence analysis of 165 rRNA genes. Appl Environ Microbiol. 2008;74:188-99.

31. Crump BC, Hobbie JE. Synchrony and seasonality in bacterioplankton communities of two temperate rivers. Limnol Oceanogr. 2005;50:1718-29.

32. Manz W, Wendt-Potthoff K, Neu TR, Szewzyk U, Lawrence JR. Phylogenetic composition, spatial structure, and dynamics of lotic bacterial biofilms investigated by fluorescent in situ hybridization and confocal laser scanning microscopy. Microb Ecol. 1999;37:225-37.

33. Araya R, Yamaguchi N, Tani K, Nasu M. Change in the bacterial community of natural river biofilm during biodegradation of aniline-derived compounds determined by denaturing gradient gel electrophoresis. J Health Sci. 2003:49:379-85.

34. Wey JK, Juergens K, Weitere M. Seasonal and successional influences on bacterial community composition exceed that of protozoan grazing in river biofilms. Appl Environ Microbiol. 2012;78:2013-24.

35. Espeland EM, Francoeur SN, Wetzel RG. Influence of algal photosynthesis on biofilm bacterial production and associated glucosidase and xylosidase activities. Microb Ecol. 2001;42:524-30.

36. Glud RN, Kuhl M, Kohls O, Ramsing NB. Heterogeneity of oxygen production and consumption in a photosynthetic microbial mat as studied by planar optodes. J Phycol. 1999;35:270-9. 
37. Fenchel T, Glud RN. Benthic primary production and O-2-CO2 dynamics in a shallow-water sediment: spatial and temporal heterogeneity. Ophelia. 2000;53:159-71.

38. Stewart PS, Franklin MJ. Physiological heterogeneity in biofilms. Nat Rev Microbiol. 2008;6:199-210.

39. Shields A. Application of similarity principles and turbulence research to bed-load movement. Pasadena, CA: California Institute of Technology; 1936. p. 43-58.

40. Righetti M, Lucarelli C. May the Shields theory be extended to cohesive and adhesive benthic sediments? J Geophys Res. 2007;112:C05039. doi:10.1029/ 2006JC003669.

41. Anderson A, Spears B, Lubarsky H, Davidson I, Gerbersdorf S, Paterson D. Magnetic particle induction and its importance in biofilm research. In: Fazel-Rezai R, editor. Biomedical Engineering - Frontiers and Challenges. Rijeka: InTech; 2011. p. 189-216.

42. Austen I, Andersen TJ, Edelvang K. The influence of benthic diatoms and invertebrates on the erodibility of an intertidal a mudflat, the Danish Wadden Sea. Estuar Coast Shelf Sci. 1999:49:99-111.

43. Gerbersdorf SU, Bittner R, Lubarsky H, Manz W, Paterson DM. Microbial assemblages as ecosystem engineers of sediment stability. J Soils Sediments. 2009:9:640-52.

44. Spears BM, Saunders JE, Davidson I, Paterson DM. Microalgal sediment biostabilisation along a salinity gradient in the Eden Estuary, Scotland: unravelling a paradox. Mar Freshw Res. 2008;59:313-21.

45. Thom M, Schmidt H, Wieprecht S, Gerbersdorf S. Physikalische Modellversuche zur Untersuchung des Einflusses von Biofilm auf die Sohlenstabilität. Wasserwirtschaft. 2012;6:32-6.

46. Gerbersdorf SU, Schubert H. Vertical migration of phytoplankton in coastal waters with different UVR transparency. Environ Sci Eur. 2011;23:36.

47. Gerbersdorf SU, Manz W, Paterson DM. The engineering potential of natural benthic bacterial assemblages in terms of the erosion resistance of sediments. FEMS Microbiol Ecol. 2008;66:282-94.

48. Dubois M, Gilles KA, Hamilton JK, Rebers PA, Smith F. Colorimetric method for determination of sugars and related substances. Anal Chem. 1956:28:350-6.

49. Raunkjaer K, Hvitvedjacobsen T, Nielsen PH. Measurement of pools of protein, carbohydrate and lipid in domestic wastewater. Water Res. 1994:28:251-62.

50. Frolund B, Palmgren R, Keiding K, Nielsen PH. Extraction of extracellula polymers from activated sludge using a cation exchange resin. Water Res. 1996;30:1749-58

51. Battarbee R. Diatom analysis. Handbook of Holocene Palaeoecology and Palaeohydology. New York: John Wiley \& Sons Ltd; 1986.

52. Hofmann G, Werum M, Lange-Bertalot H. Diatomeen im Süßwasser-Benthos von Mitteleuropa. A.R.G. Gantner Verlag K.G: Ruggell; 2011.

53. Krammer K, Lange-Bertalot H. Bacillariophyceae. In Ettl H, Gerloff J, Heyning $H$, Mollenhauer D, editors. Süßwasserflora von Mitteleuropa Band 1-4. Jena: Gustav Fischer Verlag; 1986-1991

54. Rosef O, Kapperud G, Lauwers S, Gondrosen B. Serotyping of Campylobacter jejuni, Campylobacter coli, and Campylobacter laridis from domestic and wild animals. Appl Environ Microbiol. 1985;49:1507-10.

55. Lane D. 16S/23S rRNA sequencing. In: Stackebrandt E, Goodfellow M, editors. Nucleic acid sequencing techniques in bacterial systematics. New York: Wiley; 1990. p. 115-48.

56. Emtiazi F, Schwartz T, Marten SM, Krolla-Sidenstein P, Obst U. Investigation of natural biofilms formed during the production of drinking water from surface water embankment filtration. Water Res. 2004;38:1197-206.

57. Muyzer G, Dewaal EC, Uitterlinden AG. Profiling of complex microbia populations by denaturing gradient gel electrophoresis analysis of polymerase chain reaction-amplified genes coding for 165 rRNA. Appl Environ Microbiol. 1993:59:695-700.

Submit your manuscript to a SpringerOpen ${ }^{\odot}$ journal and benefit from:

- Convenient online submission

- Rigorous peer review

- Immediate publication on acceptance

- Open access: articles freely available online

- High visibility within the field

- Retaining the copyright to your article

Submit your next manuscript at $>$ springeropen.com 